lást a kritikai véleménnyel szemben, nem okoz blokkoló szégyenérzést, hanem a jobbítás szándékát ébreszti abban, akinek szól.

Beszélgetéseink témája többször volt a pedagógus személyiségének az integritása. Hitelesnek kell lenni. Zsuzsa hitelessége nem kérdéses. Hatásának ez az egyik ereje. Minden mondatából, minden odafordulásából a másik emberhez érzékelhető a valódi érdeklődés, a valódi segíteni akarás és segíteni tudás.

\title{
„EMBERSÉGES PEDAGÓGIA”
}

\author{
KóCZÉ ANGÉLA \\ az MTA Szociológiai Intézetének \\ szociológusa \\ angelakocze@hotmail.com
}

Kereszty Tanárnőt a „differenciált tanítási módszerek” címü szemináriumi óráján ismertem meg. Az első meglepetés az volt, hogy ő volt az egyetlen tanár a föiskolán, aki kérte, tegezzük. A decens, nagyon összeszedett megjelenésű nő a következöket mondta: „Kérlek benneteket, hogy tegezödjünk, hiszen egyrészt mi kollegák vagyunk, másrészt a tisztelet nemcsak nyelvben, hanem az egymásközti viszonyban is kifejezhetö." Úgy éreztem, falak omlanak le és itt valami más forgatókönyvnek kell léteznie, ami összehasonlíthatatlanul más volt, mint amit addig tapasztaltam. Továbbá azt kérte még, hogy húzzunk össze padokat és alakítsunk ki csoportokat, mert azt szeretné, ha a csoportok együtt beszélnék át azokat a témákat és problémákat, amelyeket az óra keretében fogunk tárgyalni. Azt gondoltam, hogy ez a megközelítés az, ami igazán közel áll hozzám. Először is kollégaként kezel, aztán felborítja a megszokott szemináriumi ülésrendet, és azt kéri, hogy dolgozzak és gondolkodjak másokkal együtt. Minden órán úgy éreztem, egyre közelebb kerülök hozzá, annak ellenére, hogy még nem volt alkalmam beszélni vele. A mondatai, a problémákat sok szempontból megközelítő hozzáállása, a humanista értékrendje egyre komfortosabbá tette számomra a tanítóképző föiskola közegét, amiben az én akkori nagyon instabil roma identitásom az, ,idegent” jelentette.

Kereszty Zsuzsa volt az, akinek az óráján hallottam elöször romákról olyan kontextusban, amiben nem a szégyen és öngyülölet lett úrrá rajtam, hanem méltósággal élhettem meg a saját identitásomat. Mindig azt éreztem, hogy van valami közös titkunk, amit a többiek nem érthetnek meg, hiszen nekik nincs tapasztalásuk erröl. Ez az volt, hogy Zsuzsának nagy tapasztalata gyült össze arról, hogy hogyan 
lehet roma gyerekeket iskolában sikeressé tenni, nekem pedig saját tapasztalásom volt romaként megélni az iskolarendszer merevségét.

Az egyik legemlékezetesebb beszélgetésem Zsuzsával akkor történt, amikor a növérem már több mint három hónapja kómában feküdt, és én éppen ott akartam hagyni a föiskolát azért, hogy az ő gyerekeinek segítsek. A beszélgetésünk arról folyt, hogy mi a helyes: itt hagyni az elkezdett tanulmányaimat, és hazamenni egy szabolcsi kisfaluba, vagy küzdeni és befejezni a föiskolát. Zsuzsa a döntést meghagyta nekem, ugyanakkor megbeszéltünk minden lehetséges szcenáriót, ami az egyik vagy a másik döntésemből adódhat. Miután elköszöntem tőlem egy könyvet nyomott a kezembe. A szobából kilépve megpillantottam a borítót. Polcz Alaine „Asszony a fronton" címü regénye volt. Ez a könyv azóta is meghatározó számomra, hiszen azt adta nekem, amit Zsuzsa is közvetített direkt és indirekt módon személyiségével, tanításokon és beszélgetéseken keresztül. Ez nem más, mint az, hogyan lehet megmaradni embernek és emberségesnek a méltatlan szenvedések, testi és lelki kínzások ellenére. A könyv elolvasása után vállaltam a további „,szenvedést” és megpróbáltatást, folytattam a föiskolát. S aztán amikor tudtam, hazamenten és támogattam a nővérem gyerekeit.

Zsuzsa, mint egy igazi mentor, nemcsak a döntéseimben segített, hanem lehetőségeket is teremtett számomra. Én vidéki lányként nagyon kevés kapcsolati tőkével rendelkeztem. Ö volt az, aki bemutatott az Autonómia Alapitvány akkori igazgatójának, ahol később dolgozhattam is olyan projekteken, amelyek roma közösségeknek nyújtottak megélhetési lehetőségeket. Zsuzsa volt az, aki saját kapcsolatrendszerén keresztül lehetőséget teremtett nekem arra, hogy egy egész nyarat Angliában tölthessek. Ennek a nyárnak köszönhetem azt, hogy megtanultam angolul, aztán az egyetemi és később a doktori tanulmányaimat is angolul folytathattam.

Kereszty Zsuzsa az az ember, aki nemcsak elméleti szinten tud beszélni az integrációról és esélyegyenlőségről, hanem valós - számomra sorsfordító - tettein keresztül vált az életem egyik legmeghatározóbb személyévé. 